\title{
PENGGUNAAN PASTA CAP BEBAS MINYAK PADA PENCAPAN KAIN KAPAS DENGAN ZAT WARNA ACRAMINE
}

\author{
Agus Taufiq ${ }^{1}$, Riski Ayu Nurmansyah ${ }^{2}$, Nisrina Qurotu Ain ${ }^{3}$ \\ Jurusan Teknik Kimia, Fakultas Teknologi Industri, Universitas Islam Indonesia ${ }^{1,2,3)}$, \\ Jl. Kaliurang KM 14,5 Sleman Yogyakarta, 55584 \\ E-Mail :agustaufiq@uii.ac.id ${ }^{1}$,auggie_my@yahoo.com ${ }^{2,3)}$
}

\begin{abstract}
The comfort and absorbency properties of the cotton fiber solution make it widely used both as a standalone raw material and as a mixture with artificial fibers. Likewise in the process of printing, cotton fabrics also play an important role as textile materials are widely used because of better result than other textile materials. Printing cotton fabrics with dye pigments made with pasta cap emulsion containing oil, so that environmental pollution problems will always arise, for that it is necessary to overcome or minimize the risk of environmental pollution as a result of the printing process, using a pasta stamp that is free from petroleum solvents. This study examines the use of oil-free paste stamps on the printing of cotton fabrics with acramine dyes. Paste stamp is made using a synthetic thickener with the amount of thickener usage varies from $5 \mathrm{~g}, 10 \mathrm{~g}, 15 \mathrm{~g}, 20 \mathrm{~g}$ and $25 \mathrm{~g}$ as well as the temperature variation of the preserved heater by 1300C; 1400C; and 1500C using the dye pigments acramine as much as $20 \mathrm{~g}$ with a heater mounted for 3 minutes. The results of the study (with a quality evaluation in terms of aging color and color dispersion) indicates that the greater the amount of thickener used, the color that occurs increasingly older, while higher temperatures The preheated heater relative does not affect the color aging. The optimum results in this study were achieved on the use of thickener of $20 \mathrm{~g}$ and the preserved heating temperature of 1500C. When compared with the use of an emulsion paste cap (using an oil solvent), the result of the stamp using a solution-free (systemsolvent-free) solution cap stamp gives a nearly equal and good value.
\end{abstract}

Keywords : Cotton, Synthetic Thickener, Acramine, Preset Heater, Colour Aging.

\section{PENDAHULUAN}

\subsection{Umum}

Pada dasarnya pencapan merupakan proses pewarnaan melalui mekanisme pelekatan zat warna secara setempat pada bahan sehingga menimbulkan motif atau corak tertentu.

Pencapan pada bahan (kain) dari serat kapas telah banyak dikembangkan termasuk penggunaan pasta cap dari zat warna pigmen pada pencapan kain kapas juga bukan merupakan hal baru, dan telah banyak diterapkan dalam pabrik maupun dalam industri rumah karena mempunyai kemudahan - kemudahan antara lain : pembuatan pasta capnya sederhana, tidak memerlukan pengerjaan iring setelah pencapan; zat warnanya dapat dipakai bersama-sama dengan zat warna lain; dan dapat dipakai hampir untuk semua jenis serat.
Namun demikian juga menyisakan suatu masalah diantaranya berkaitan dengan pencemaran lingkungan, karena penggunaan emulsi (pelarut minyak). Oleh karena itu perlu diupayakan jenis pasta cap yang bebas dari pelarut minyak, khususnya pada pencapan kain dari serat kapas.

\subsection{Latar Belakang Masalah}

Zat warna pigmen telah banyak dirasakan manfaatnya dalam dunia pencapan termasuk untuk kain dari bahan baku serat kapas, tetapi pemakaian pasta capnya masih terbatas pada sistem emulsi yang menggunakan pelarut minyak, sedangkan sistem larutan yang memungkinkan untuk dilakukan justru tidak pernah digunakan.

Pencapan dengan menggunakan pasta cap sistem emulsi yang umum dipakai terdapat beberapa kerugian antara lain : 
1. Kemungkinan timbulnya pencemaran lingkungan akibat pembuangan gas dari minyak ke udara.

2. Kemungkinan terjadi ledakan dalam mesin pengeringan (curing).

3. Bersama - sama dengan naiknya hargaharga produk petrolium maka minyak tanah atau bensin akan naik sehingga biaya produksi juga akan meningkat.

Oleh karenanya penggunaan pasta cap yang bebas dari pelarut minyak dan hanya menggunakan pelarut air pada bahan (kain) dari serat kapas yang mempunyai daya serap dan kenyamanan dalam pemakaian yang baik perlu dilakukan dan dikembangkan.

Dengan pasta cap sistem larutan yang hanya menggunakan pelarut air ini disamping sederhana dalam pembuatan pastanya juga kemungkinan timbulnya bahaya dan efek sampingan lain termasuk pencemaran lingkungan dapat diperkecil.

\subsection{Rumusan Masalah}

1. Bagaimana pasta cap bebas pelarut minyak diterapkan pada pencapan kain kapas dengan pengental sintetik menggunakan zat warna acramine?

2. Seberapa jauh pengaruh jumlah pemakaian pengental terhadap kualitas (ketuaan warna) kain hasil pencapan?

3. Pada kondisi proses berapakah dapat dicapai hasil yang paling baik?

\subsection{Batasan Masalah}

Dalam penelitian ini dibatasi beberapa hal guna lebih fokus dalam Mengkaji pengaruh suatu variabel terhadap kualitas hasil proses pencapan yang dilakukan dalam penelitian, diantaranya :

1. Bahan yang digunakan sebagai media pencapan adalah kain kapas $100 \%$, dengan zat warna pigmen jenis acramine dan pengental yang digunakan yaitu pengental sintetik (jenis alcoprint) dan pelarut untuk membentuk pasta hanya air.
2. Variabel yang digunakan adalah jumlah pengental (divariasikan sebesar $5 \mathrm{~g}, 10 \mathrm{~g}$, $15 \mathrm{~g}, 20 \mathrm{~g}$ dan $25 \mathrm{~g}$ ) dan serta suhu pemanas awetan (divariasikan sebesar $130^{\circ} \mathrm{C} ; 140^{\circ} \mathrm{C}$; dan $150^{\circ} \mathrm{C}$ ), dengan pemakaian zat warna sebanyak $20 \mathrm{~g}$ dan waktu pemanas awetan selama 3 menit.

3. Evaluasi mutu hasil pencapan dilakukan dalam hal ketuaan warna dan kerataan (nilai beda warna).

\subsection{Tujuan Penelitian}

1. Untuk mengetahui pengaruh pemakaian jumlah pengental dan suhu pemanas awetan terhadap ketuaan dan kerataan warna hasil pencapan kain kapas dengan pasta cap yang bebas dari pelarut minyak.

2. Mengetahui kondisi proses yang memberikan hasil pencapan yang optimal.

\subsection{Manfaat Penelitian}

Penelitian ini dapat memberi alternatif solusi untuk mengurangi pencemaran lingkungan yang ditimbulkan oleh industri tekstil khususnya industri pencapan (printing).

\section{TINJAUAN TEORI}

\subsection{Serat Kapas}

Meskipun perkembangan serat sintetik sudah demikian pesat, namun pemakaian serat-serat alam terutama kapas masih memegang peranan penting dalam Pertekstilan.

Serat kapas dihasilkan dari rambut biji tanaman yang termasuk dalam jenis Gossypium dari keluarga Malvaceae. Serat kapas tersebut merupakan serat tunggal yang salah satu ujungnya melekat pada epidemik biji kapas. Kumpulan dari serat-serat kapas tersebut menyerupai rambut-rambut yang keluar dari biji kapas dan mengandung kadar selulose yang tinggi, oleh karenanya digolongkan kedalam jenis serat selulose (serat alam) yang berasal dari biji - bijian.

Serat kapas terdiri dari selulose, minyak malam, pectin, lemak, protein, pigmen alam, asam - asam orgnik, dan air serta mineral 
dan zat - zat yang mengandung nitrogen. Dari komponen yang terdapat pada serat kapas tersebut, selulosa merupakan komponen utamanya. Selulosa juga merupakan penyusun dinding sel tanaman, kandungan selulosa pada dinding sel tanaman tingkat tinggi sekitar $35-50 \%$ dari berat kering tanaman. Selulosa merupakan polimer glukosa dengan ikatan $\beta-1,4$ glukosida dalam rantai lurus. Bangun dasar selulosa berupa suatu selobiosa yaitu dimer dari glukosa. Rantai panjang selulosa terhubung secara bersama melalui ikatan hidrogen dan gaya van der Waals. Selulosa mengandung sekitar 50-90\% bagian berkristal dan sisanya bagian amorf. Selulosa hampir tidak pernah ditemui dalam keadaan murni di alam, melainkan selalu berikatan dengan bahan lain seperti lignin dan hemiselulosa. Selulosa terdapat dalam tumbuhan sebagai bahan pembentuk dinding sel dan serat tumbuhan.

Dalam hal struktur kimia dari serat kapas dapat dijelaskan bahwa analisa kwantitatif dan hidrolisa serat kapas yang telah mengalami pemurnian sehingga tinggal selulosenya, menunjukkan bahwa selulose tersebut tersusun dari gabungan zat-zat glukosa yang membentuk polimer dimana glukosa-glukosa tersebut mempunyai dua bentuk stereo yaitu $\alpha$ dan $\beta$ glukosa. Apabila selulosa diasetilasi dan kemudian dihidrolisa secara tidak sempurna maka akan diperoleh suatu bentuk okta asetan dari selubiosa. Selubiosa terdiri dari gabungan dua molekul glukosa yang dihubungkan pada posisi 1 dan 4. ikatan 1 dan 4 ini terjadi apabila gugus hidroksil dari atom $\mathrm{C}$ nomor 1 dari molekul glukosa yang satu berkondensasi dengan gugus hidroksil pada atom $\mathrm{C}$ nomor 4 dari molekul glukosa yang lain. Derajat polimerisasi selulosa pada kapas kira-kira 10.000 dengan berat molekul kira-kira 1.580.000. Adapun struktur molekul dari selulosa dapat terlihat seperti pada gambar berikut.

Molekul selulosa merupakan mikrofibil dari glukosa yang terikat satu dengan lainnya membentuk rantai polimer yang sangat panjang. Adanya lignin serta hemiselulosa di sekeliling selulosa merupakan hambatan utama untuk menghidrolisis selulosa. Selain itu selulosa merupakan polisakarida yang terdiri atas satuan-satuan dan mempunyai massa molekul relatif yang sangat tinggi, tersusun dari 2.000-3.000 glukosa. Rumus molekul selulosa adalah $\left(\mathrm{C}_{6} \mathrm{H}_{10} \mathrm{O}_{5}\right) \mathrm{n}$. Selulosa merupakan komponen utama penyusun dinding sel tanaman yaitu senyawa polimer glukosa yang tersusun dari unit -

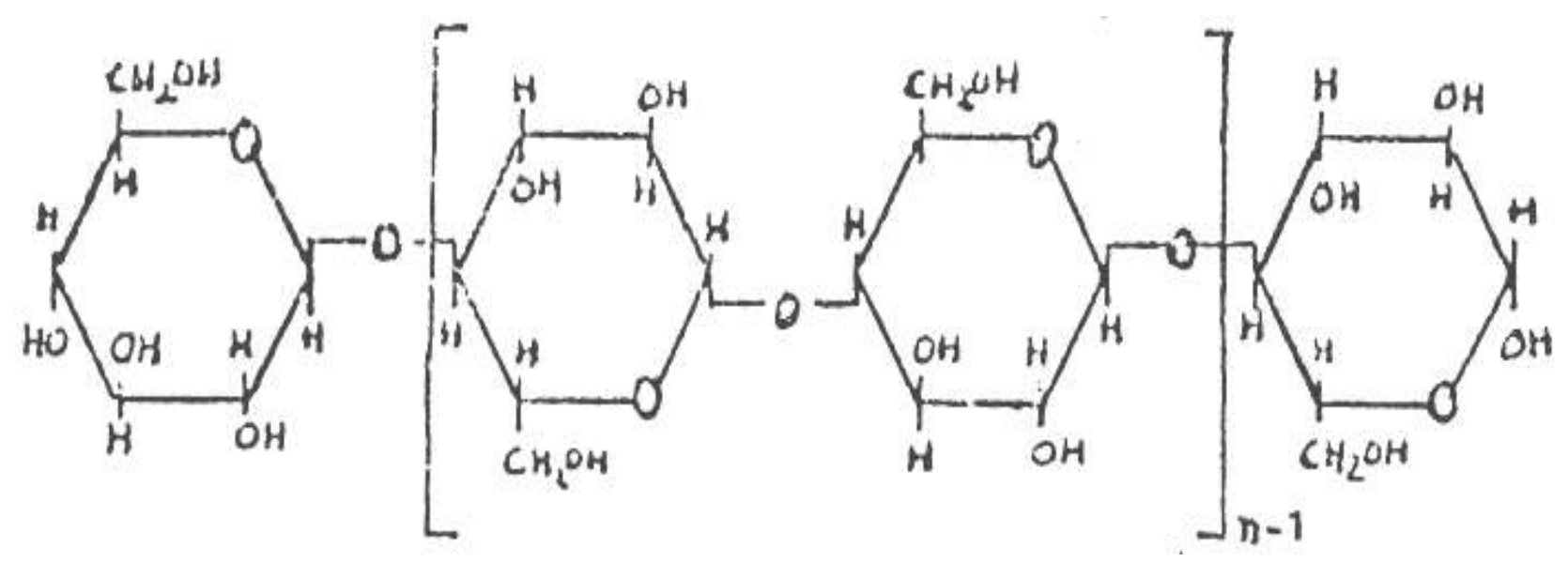

Gambar 1. Struktur Molekul Serat Kapas.

(Sumber : Supriyono.P. et.al . Serat-Serat Tekstil. Cetakan ke2.

Bandung : Institute Teknologi Tekstil, 1974, hal 45) 
Tabel 1. Komposisi Kimia Serat Kapas

(Sumber : Rasyid Djufri, et al. 1976, Teknologi Pengelantangan Pencelupan Dan Pencapan. Cetakan ke 2, Bandung : Institut Teknologi Tekstil, halaman 21)

\begin{tabular}{cc}
\hline JENIS ZAT & JUMLAH (\%) \\
\hline Selulose & $80-85$ \\
Protein dan zat-zat yang mengandung N & $1-2,8$ \\
Lemak, malam dan lain-lain & $0,5-1$ \\
Pektin dan pektosa & $0,4-1$ \\
Zat-zat mineral, pigmen dan resin & $3-5$ \\
Air & $6-8$ \\
\hline
\end{tabular}

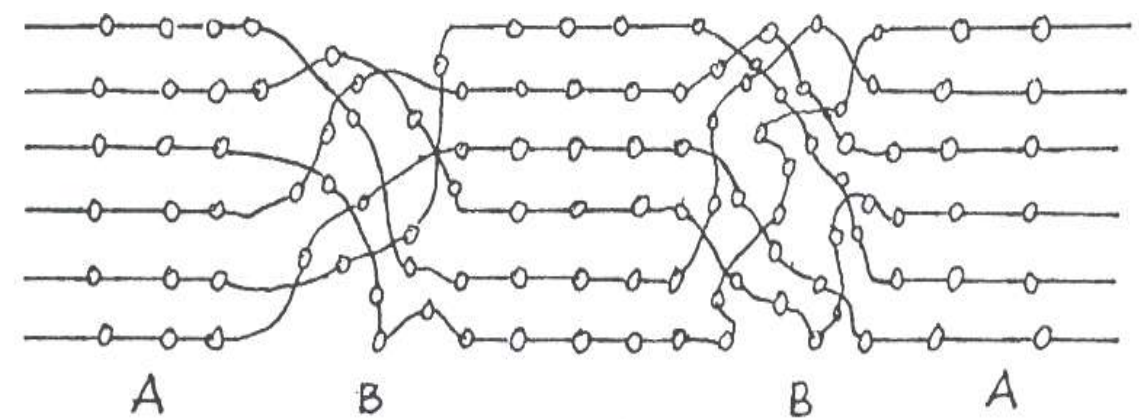

Gambar 2. Bentuk Amorf dan Kristalin Dari Serat Kapas.

Sumber : Mathew's, 1993, Textile Fibre. New York Jhon WilleyAnd Sons. Inc.

Keterangan gambar :

A. Bagian Kristalin.

B. Bagian Amorf.

unit $\beta$-1,4-glukosa yang dihubungkan dengan ikatan $\beta-1,4-\mathrm{D}$ glukosida. Ikatan $\beta-1,4$ glukosida pada serat selulosa dapat dipecah menjadi monomer glukosa dengan cara hidrolisis asam atau enzimatis. Hidrolisis sempurna selulosa akan menghasilkan monomer selulosa yaitu glukosa, sedangkan hidrolisis tidak sempurna akan menghasilkan disakarida dari selulosa yaitu selobiosa. Zatzat selain selulose seperti kotoran, lemak, malam dan sebagainya dapat dihilangkan dengan proses pemasakan. Lebih jelasnya komposisi kimia dari serat kapas yang terdapat pada tabel 1 .

Menurut Meyer (Mathews, 1993) dalam pengamatan di bawah sinar X menunjukkan bahwa sebagian besar selulosa terdiri dari bentuk kristal $( \pm 75 \%)$ dan sebagian lagi adalah bagian amorf $( \pm 25 \%)$. Hal ini dapat terlihat seperti pada gambar 2 .
Bagian amorf mempunyai daya serap besar dan kekuatan lebih rendah apabila dibandingkan dengan bagian kristalin. Pada bagian amorf letak dan jarak antara molekul selulose tidak teratur ada yang kecil ada yang besar. Pada jarak yang besar inilah molekul-molekul air dapat masuk dan mengakibatkan penggelembungan serat. Sedangkan pada bagian kristalin letak dan jarak antara molekul selulose tersusun sejajar satu sama lainnya dengan teratur.

Adapun sifat - sifat kimia dari serat kapas antara lain yaitu serat kapas cukup tahan terhadap alkali pada kondisi tertentu, selain itu alkali lemah seperti $\mathrm{Na}_{2} \mathrm{CO}_{3}$ tidak berpengaruh terhadap serat kapas baik pada suhu rendah maupun tinggi selama tidak ada oksigen dari udara. Pada suhu tinggi dan pengaruh oksigen dari udara dapat menyebabkan terjadinya oksiselulosa. 
Sedangkan larutan - larutan alkali pekat pada suhu kamar dapat menggembungkan serat kapas, tetapi pada suhu agak tinggi akan membentuk oksiselulosa. Selulosa akan terhidrolisa oleh asam, yang menghasilkan hidroselulosa dan membentuk rantai - rantai molekul yang lebih pendek karena putusnya ikatan - ikatan antara satuan-satuan glukosa dalam rantai selulosa. Dalam larutan asam sulfat pekat, kapas akan larut dengan cepat. Asam - asam anorganik encer apabila dibiarkan mengering pada serat kapas akan menurunkan kekuatan serat. Serat kapas tahan terhadap kondisi penyimpanan, pengolahan dan pemakaian yang normal, tetapi beberapa zat pengoksidasi dan penghidrolisa menyebabkan kerusakan sehingga terjadi penurunan kekuatan.

Asam-asam seperti $\mathrm{HCl}, \mathrm{H}_{2} \mathrm{SO}_{4}$ menyebabkan ikatan - ikatan glukosa dalam rantai selulosa membentuk hidroselulosa. Serat kapas sedikit terpengaruh oleh alkali encer, tetapi dengan alkali kuat serat kapas akan mengalami penggelembungan. Zat oksidator menyebabkan kerusakan (oksiselulosa) dan penurunan kekuatan serat. Kapas mudah diserang bakteri dan jamur terutama di tempat - tempat yang lembab dan suasana hangat. Jamur dan bakteri dapat memutuskan rantai - rantai selulosa.

Air mempunyai pengaruh terhadap serat kapas karena dalam keadaan basah kapas akan menggelembung kearah panjang biasanya tidak lebih dari 1\%. Sedangkan sifat fisika meliputi warna (biasanya sedikit krem), kekuatan rata per bundel adalah 96.700 pound per inch ${ }^{2}$; mulur saat putus serat berkisar $4-13 \%$ bergantung pada jenisnya, dengan mulur rata - rata $7 \%$; keliatan (ukuran yang menunjukkan kemampuan suatu benda untuk menerima kerja, dan merupakan sifat yang penting untuk serat - serat tekstil terutama untuk keperluan industri); kekakuan (daya tahan terhadap perubahan bentuk, biasanya dinyatakan sebagai perbandingan antara kekuatan saat putus dengan mulur saat putus), moisture regain serat kapas bervariasi dengan perubahan relatif atmosfir sekelilingnya.
Moisture Regain serat kapas pada kondisi standar berkisar antara 7-8,5\%; berat jenis berkisar 1,50 sampai 1,56, indek bias kapas sejajar sumbu serat 1,58 , indek bias melintang sumbu serat 1,53.

Dalam keadaan lembab dan hangat serat kapas mudah terserang oleh jamur dan bakteri, yang berakibat serat rusak sehingga kekuatannya menurun. Selain tu dapat juga timbul bintik - bintik warna yang tidak diinginkan. Serat kapas tidak memperlihatkan perubahan kekuatan apabila dipanaskan selama 5 jam pada suhu $120^{\circ} \mathrm{C}$, tetapi pada suhu yang lebih tinggi dapat menurunkan kekuatannya. Serat kapas hampir kehilangan kekuatannya dengan sempurna apabila dipanaskan beberapa jam pada suhu $240^{\circ} \mathrm{C}$.

Serat kapas memiliki sifat-sifat fisik antara lain yaitu warna, biasanya agak krem atau putih kekuningan, jadi tidak putih benar. Warna kapas ini ditimbulkan oleh adanya pigmen alam di dalam serat, dan makin tua dalam penyimpanan. Sifat kekuatan, terutama dipengaruhi oleh kadar selulosa dalam serat, panjang rantai dan orientasinya. Serat kapas dalam keadaan basah menggelembung berbentuk silinder, sehingga distribusi tegangan lebih merata dan kekuatan seratnya akan naik. Apabila gaya diberikan terhadap serat kering, maka distribusi tegangan dalam serat tidak merata karena bentuk serat kapas yang terpuntir dan tidak teratur. Dalam kondisi standar serat kapas mempunyai kandungan kelembaban antara $7-8.5 \%$. Mulur serat kapas berkisar $4-13 \%$, tergantung dari jenisnya, dengan mulur rata-rata $7 \%$. Berat jenis serat kapas, yaitu antara $1.5-1.56 \mathrm{~g} / \mathrm{cm}^{3}$ dan indeks bias, yang sejajar dengan sumbu serat yaitu 1.58 sedang indeks bias melintang serat yaitu 1.53 .

Morfologi serat kapas, pada bentuk memanjang serat kapas adalah pipih seperti pita terpuntir, dengan lebar berkisar antara 12 - 30 mikron dan mempunyai perbandingan panjang dengan lebarnya yang bervariasi dari 5.000 : 1 sampai $10.000: 1$. Kadar selulosa dalam serat, panjang rantai dan orientasinya menentukan sifat kekuatan 
dari serat kapas. Bentuk melintang serat kapas bervariasi mulai dari pipih sampai bulat, tetapi umumnya berbentuk seperti ginjal. Dengan lapisan - lapisan seperti terlihat pada gambar 3 .

\subsection{Zat Warna Pigmen}

Zat warna tekstil adalah semua zat berwarna yang mempunyai kemampuan untuk diserap oleh serap tekstil dan mudah dihilangkan kembali. Suatu zat dapat berlaku sebagai zat warna apabila mempunyai gugus yang dapat menimbulkan warna (kromofor) dan dapat mengadakan ikatan dengan serat tekstil. Kromofor berasal dari kata Chromophore yang berasal dari bahasa yunani yaitu Chroma yang berarti warna dan phoros yang berarti mengemban. Zat warna yang dipergunakan untuk pencapan, seperti halnya zat warna yang akan dipergunakan untuk pencelupan, yaitu harus dilarutkan atau didispersikan dahulu dalam air atau zat pelarut atau pendispersi lain, agar dapat campur homogen dengan bahan - bahan lain yang dipergunakan dalam pencapan tersebut.
Tentu saja dalam melarutkan atau mendispersikan warna tersebut dengan ditambah zat-zat kimia atau zat pembantu lain yang bersifat memperbaiki daya larut zat warna, dengan tidak merubah sifat-sifat zat warna yang telah ada. Pemakaian zat kimia atau zat pembantu disini tergantung dari jenis zat warna yang akan dipergunakan dalam pencapan. Kelarutan zat warna dalam pencampuran adalah merupakan syarat mutlak untuk mendapatkan hasil cap yang baik. Untuk mempermudah larutannya atau dispersinya zat warna, lebih dulu zat warna dibuat pasta dengan air atau zat pelarut seperti yang dikehendaki, kalau perlu dapat dipanaskan untuk mendapatkan kelarutan atau dispersi yang sempurna. Seperti dijelaskan sebelumnya bahwa zat warna yang dipergunakan untuk pencapan harus merupakan bubur dengan kepekatan tertentu, untuk dapat membuat bubur itu dalam larutan zat warna ditambahkan bahan pengental untuk pencapan mempunyai syarat - syarat tertentu antara lain :

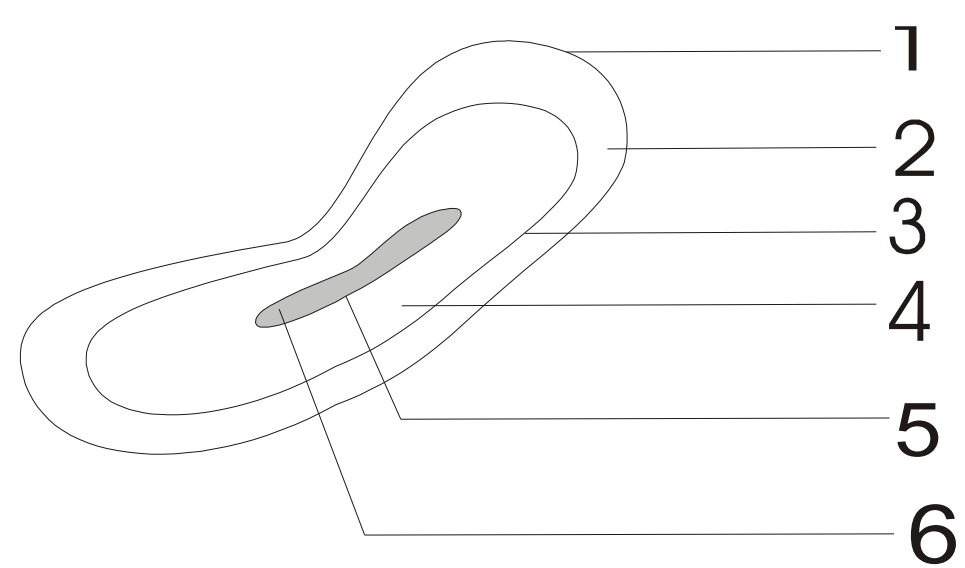

Gambar 3. Lapisan Serat Kapas.

(Sumber : Supriyono. P. et al., 1974, Serat-Serat Tekstil. Cetakan ke 2. Bandung: Institut Teknologi Tekstil)

Keterangan Gambar :

1. Kutikula, lapisan terluar terdiri dari lilin, lemak, minyak, pectin dan gom.

2. Dinding primer, terdapat sedikit pectin, protein dan lilin.

3. Lapisan antara, merupakan lapisan pertama dari dinding sekunder,

4. Dinding sekunder, adalah lapisan selulosa yang utama dari serat kapas.

5. Dinding lumen, yang lebih tahan terhadap pereaksi - pereaksi tertentu dibanding dinding sekunder.

6. Lumen, yaitu lapisan serat yang berupa rongga dan mengandung protoplasma kering yang terdiri dari sebagian nitrogen. 
1. Mempunyai viskositas yang tertentu dan stabil untuk jangka waktu tertentu, tidak terjadi perubahan-perubahan kimia dan fisika.

2. Tidak akan merusak zat warna.

3. Mudah dihilangkan pada proses pencucian, kecuali pengental zat warna pigmen.

Zat warna warna pigmen merupakan pewarna yang tidak larut dalam air dan segala macam pelarut. Pigmen juga tidak akan larut dalam medium waktu dalam pemakaian dan dan tidak larut dalam medium yang diwarnai baik waktu proses pewarnaan maupun selama bahan dalam pemakaian. Zat warna yang digunakan untuk pencapan, seperti halnya zat warna yang akan dipergunakan untuk pencelupan, yaitu harus dilarutkan atau didispersikan dahulu dalam air atau zat pelarut atau pendispersi lain, agar dapat campur homogen dengan bahan - bahan lain yang dipergunakan dalam pencapan tersebut. Tentu saja dalam melarutkan atau mendispersikan warna tersebut dengan ditambah zat - zat kimia atau zat pembantu lain yang bersifat memperbaiki daya larut zat warna, dengan tidak merubah sifat - sifat zat warna yang telah ada. Pemakaian zat kimia atau zat pembantu disini tergantung dari jenis zat warna yang akan dipergunakan dalam pencapan. Kelarutan zat warna dalam pencampuran adalah merupakan syarat mutlak untuk mendapatkan hasil cap yang baik.

Zat warna pigmen tidak mempunyai subtantivitas terhadap serat, oleh karenanya pigmen pada dasarnya berbeda dengan zat warna lainnya yang larut. Dan pada pemakaiannya untuk bahan tekstil memerlukan bantuan suatu zat pengikat (binder) yang berfungsi untuk membantu pengikatan zat warna pada serat.

Bergantung pada cara pembuatannya, zat warna pigmen dibuat dengan berbagai macam ukuran partikel. Ukuran partikel yang lebih besar akan memberikan warna yang kurang cerah dan lebih sukar tertutup oleh zat pengikatnya, sehingga memberikan daya tahan yang kurang. Sedang ukuran pertikel yang lebih kecil memberikan warna yang cerah, karena partikel - partikel ini akan tetap berada di permukaan sehingga pada reflektansinya akan memberikan kilau yang tinggi.

Ukuran partikel pigmen dalam perdagangan berkisar antara $0,1-1 \mu$. Parikel yang lebih kecil dari $0.1 \mu$ akan menyebabkan warna kurang cerah, karena partikelnya lebih meresap kedalam pori pori serat. Sedang yang lebih besar dari 0,5 $\mu$ ternyata juga kurang cerah. Oleh karenanya ukuran partikel yang paling baik berkisar antara 0,2 - 0,5 $\mu$.Dan kekuatan pewarnaannya pun dipengaruhi oleh ukuran partikelnya.

Menurut Jones F. George (1996), pigmen pada umumnya termasuk ke dalam klasifikasi sebagai berikut :

a. Garam anorganik, misalnya $\mathrm{Pb} \mathrm{Cr} \mathrm{O}_{3}$, Cd S.

b. Oksida anorganik, misalnya $\mathrm{Fe}_{2} \mathrm{O}_{3}$, $\mathrm{Cr}_{2} \mathrm{O}_{3}$

c. Logam - logam berwarna, misalnya $\mathrm{Al}$, Ca.

d. Senyawa organik golongan azo, misalnya Pigmen naphtol.

e. Senyawa organik kompleks logam misalnya Phtalocyanine.

f. Senyawa organik golongan bejana misalnya Thioindigo.

Ada pengecualian dari klasifikasi tersebut, tetapi hampir semua pigmen yang berguna untuk industri tekstil termasuk ke dalam klasifikasi tersebut. Sedang yang paling banyak digunakan untuk pencelupan dan pencapan adalah dari jenis azo, bejana, kompleks logam dan logam berwarna.

Dalam perdagangan, zat warna pigmen dikenal dengan nama dagang Aridye (USA); Orema (Cuba); Printofix (Sandox); Imperon; Acramin (Bayer); Alcian (ICI); Neopralac (Franc color); Sandye (Sanyo); dan sebagainya.

Adapun sifat - sifat yang dimiliki zat warna pigmen adalah arah warna (kecerahan) mempunyai perbedaan yang jelas satu dengan yang lainnya. 
Dalam bentuk larutan kokoida, ukuran partikel tidak berubah (akan stabil). Sebelum berada dalam larutan padding, berat molekulnya tetap. Mempunyai ketahanan yang cukup terhadap panas.

Zat warna pigmen merupakan zat warna yang dapat digunakan untuk mencap semua jenis bahan tekstil (termasuk kain campuran polyester / kapas) sehingga banyak digunakan. Zat warna ini tidak mempunyai gugus pelarut atau gugus yang dapat berikatan dengan serat. Sifat zat warna ini hanya menempel saja pada permukaan kain dengan pengikat binder. Karena sifat yang hanya menempel saja maka hasil yang diperoleh mempunyai efek kaku. Dan untuk menghindari efek ini biasanya dalam resep yang digunakan ditambahkan zat pelembut.

Kelemahan lain yang ada pada zat warna ini adalah ketahanan terhadap gosoknya yang jelek. Pencapan dengan zat warna pigmen dapat digunakan pada semua jenis serat. Zat warna pigmen tidak mempunyai afinitas terhadap serat, maka fiksasinya ke dalam serat diperlukan bantuan zat pengikat yaitu binder. Kekuatan ikatan antara zat warna pigmen dengan serat tergantung pada daya ikat dari binder yang digunakan. Karena sifat fiksasi zat warna pigmen yang demikian, maka zat warna pigmen dapat diaplikasikan pada semua jenis serat termasuk serat - serat gelas.

Di tinjau dari segi ekonomis, metode pencapan zat warna pigmen sangat sederhana dan murah. Proses pencucian yang dimaksudkan untuk menghilangkan sisa sisa zat warna, pengental, dan zat - zat pembantu, tidak diperlukan pada metode pencapan zat warna pigmen. Oleh sebab itu metode ini sangat luas digunakan dalam industri. Dalam perkembangannya, saat ini sudah banyak diproduksi selain zat warna pigmen sintetik juga binder sintetik yang lebih menjamin hasil cap sesuai keinginan. Komponen pasta cap pigmen didasarkan pada 3 hal penting, yaitu dispersi zat warna pigmen, binder, zat pembantu ikatan silang, serta pengental yang sesuai.
Hasil pencapan pigmen yang baik ditandai dengan tingkat kecerahan yang tinggi, sifat pegangan yang tidak kaku dan sifat daya ketahanan yang tinggi terhadap gosok dan pencucian. Permukaan kain, sehinga tidak berpenetrasi lebih jauh kedalam tekstil hanya tinggal dipermukaannya saja, sehingga menghasilkan tingkat pewarnaan yang lebih baik.

Pada penggunaan pengental disperse, untuk menghindari ketidakrataan warna pada pencapan kain halus dan kain hidrofob dan juga terjadinya screen fram marks, dapat dikombinasikan dengan pengental koloid (misal dari jenis eter selulosa) yang mengurangi efek pegangan kaku jika penambahan pengental koloid semakin besar.

Sedangkan susunan kimia dari zat warna pigmen yaitu tidak mempunyai bentuk umum, karena sangat bervariasi, dari yang paling sederhana misalnya oksida logam, sampai pada susunan kimia yang kompleks misalnya phtalocyanine blue. Bentuk partikelnya dibentuk kristal agar zat warna pigmen dapat memberikan warna yang cerah. Derajat dispersinya mempunyai pengaruh terhadap kekuatan dan kilau dari lapisan pigmen, dimana lebih besar derajat dispersi, maka lebih luas permukaan per unit berat dari pigmen yang melekat pada bahan sehingga memberikan kilau yang baik.

Zat warna pigmen dapat digunakan secara tersendiri atau dicampur dengan pigmen putih seperti misalnya seng oksida; titan oksida dan timbale oksida, sebagai pengatur tua muda warnanya. Kebanyakan tinta cetak dibuat dari pigmen yang digunakan dalam pencapan lembaran logam, lempeng timah, kertas, bahan pelapis kayu kulit dan tekstil dengan atau tanpa zat perantara (perekat; pengikat, dll). Pigmen juga digunakan sebagai pewarna pada produk kosmetika; sabun; malam; kapur dan pewarna cairan polimer serat (dope dyeing). 


\subsection{Pengental}

Pengental digunakan dalam proses pencapan sebagai medium untuk melekatkan zat warna pada permukaan kain, medium air seperti halnya pada pencelupan tidak bisa digunakan karena sifat air yang menyebar sehingga menyebabkan gambar atau motif tidak tajam (merembes / boblor).

Dalam proses pencapan, pengental ini dijadikan dalam bentuk pasta bersama dengan zat - zat lain yang diperlukan untuk membentuk pasa cap. Medium (pasta cap) yang membawa zat warna pada pencapan harus memiliki viskositas atau kekentalan yang cukup agar zat warna yang dicapkan tidak keluar motif yang sudah ditentukan Pasta pengental pada pencapan berfungsi sebagai zat pembantu untuk melekatkan zat warna pada bahan, sehingga menimbulkan motif tertentu. Fluida merupakan zat cair yang jenisnya berbeda memiliki tingkat kekentalan yang berbeda. Viskositas atau kekentalan sebenarnya merupakan gaya gesekan antara molekul - molekul yang menyusun suatu fluida. Jadi molekul molekul yang membentuk suatu fluida saling bergesekan ketika fluida tersebut mengalir.

Pada zat cair, viskositas disebabkan karena adanya gaya kohesi (gaya tarik menarik antara molekul sejenis). Media pembawa zat warna pada pencapan harus memiliki viskositas atau kekentalan yang cukup agar zat warna yang dicapkan tidak keluar motif yang sudah ditentukan Pasta pengental pada pencapan berfungsi sebagai zat pembantu untuk melekatkan zat warna pada bahan, sehingga menimbulkan motif tertentu.

Fluida merupakan zat cair yang jenisnya berbeda memiliki tingkat kekentalan yang berbeda. Sedangkan dalam zat gas, viskositas disebabkan oleh tumbukan antara molekul fluida merupakan zat cair yang jenisnya berbeda memiliki tingkat kekentalan yang berbeda. Viskositas alias kekentalan sebenarnya merupakan gaya gesekan antara molekul - molekul yang menyusun suatu fluida. Jadi molekul molekul yang membentuk suatu fluida saling bergesekan ketika fluida tersebut mengalir.
Pada zat cair, viskositas disebabkan viskositas yang terlalu tinggi menyebabkan pasta cap hanya mewarnai permukaan kain saja. Sedangkan viskositas rendah berakibat hasil pencapan pastanya menyebar sehingga gambar tidak tajam, karena adanya gaya kohesi (gaya tarik menarik antara molekul sejenis).

Pengental yang membutuhkan kadar zat padat tinggi untuk memperoleh suatu tingkat viskositas tertentu disebut pengental dengan viskositas rendah. Sebaliknya pengental yang hanya sedikit membutuhkan kadar zat padat mencapai viskositas tertentu disebut dengan pengental dengan viskositas yang tinggi. Pengental yang dipakai untuk pencapan dipilih sesuai dengan kain yang dicap, jenis zat warna dan alat atau mesin yang digunakan. Pengental memiliki viskositas, daya rekat, daya penetrasi, dan elastisitas tertentu yang berbeda satu dengan yang lainnya, sehingga kadang dalam pemakaian untuk pencapan dilakukan pencampuran beberapa jenis pengental untuk mendapatkan sifat yang diinginkan dan biaya produksi yang rendah.

Pasta pengental untuk percapan harus memenuhi persyaratan tertentu diantaranya :

1. Mempunyai viskositas tertentu dan stabil dalam jangka waktu tertentu, tidak terjadi perubahan fisika maupun kimianya.

2. Tidak berwarna.

3. Tidak akan merusak serat.

4. Dapat membawa zat warna dan tidak breaksi dengan zat warnanya.

5. Mudah dihilangkan pada proses pencucian.

Dalam penelitian ini digunakan pengental dari bahan sintetik. Pengental ini merupakan pengental yang pertama diproduksi untuk pencapan sistem larutan. Dengan pengental ini, pencapan bebas dari pelarut minyak. Pengental alcoprint ini didasarkan pada senyawa asam poli akrilat yang bermolekul tinggi. Asam poli akrilat ini bila dinetralkan dengan suatu senyawa basa yang sesuai misalnya ammonia, maka asam 
tersebut akan larut sebagai ammonium poli akrilat. Garam amonium poliakrilat ini bersifat mulur sekali (long) atau seperti benang (stringly) dan menunjukkan gejala reologi yang tidak sesuai untuk pencapan. Untuk mengurangi kekurangan tersebut maka diberikan sedikit rantai cabang pada molekul polimernya sehingga molekul ini tidak larut, tetapi akan mengembung atau mengembang saja dan hasilnya tidak berbeda seperti pada sistem emulsi minyak dalam air $(\mathrm{O} / \mathrm{W})$ dimana larutan mempunyai $\mathrm{pH} 4$.

Sifat pseudoplastik ini dapat dimanfaatkan dalam proses pencapan, karena kekentalan pasta cap dapat diatur waktu proses pencapan, misalnya pengaruh rol pada pencapan rol, sehingga kekentalan pasta cap akan menurun. Sehingga, akibatnya dapat digunakan kasa atau pahatan rol yang sangat halus untuk mendapatkan hasil pencapan yang jelas motifnya.

Tidak berbeda seperti pada sistem emulsi minyak dalam air atas dasar perhitungan ekonomi, pengental sintetik ini hanya dapat menggantikan sebagian dari pelarut minyak. Akan tetapi perkembangan selanjutnya karena bertambah tingginya efisiensi pengental ditambah dengan bertambah tingginya harga minyak secara cepat, maka pemakaian pasta cap yang bebas dari minyak dalam proses pencapan perlu untuk dikembangkan.

Sedangkan sifat - sifat dan karakteristik dari pengental sintetik ini antara lain adalah sebagai berikut (Anonim, 1993) :

- Merupakan polimer akrilic, mempunyai sifat dapat larut dalam air dan cepat membentuk pasta rata / lembut, bersifat anionik, $\mathrm{pH}$ dari $1 \%$ pasta antara $5-6$ (suasana asam).

- Merupakan pengental dengan efisiensi tinggi untuk pencapan zat warna pigmen.

Pengental jenis sintetik banyak dipakai dalam pencapan karena kemurniannya dapat diandalkan dan jenis ini banyak digunakan pada pencapan zat warna pigmen, bejana dan dispersi.

\subsection{Zat Pengikat}

Binder (zat pengikat) merupakan zat kimia yang berperan penting dalam proses pencapan dengan zat warna pigmen untuk meningkatkan daya ketahanan luntur warna. Binder adalah suatu zat yang akan membentuk lapisan tipis yang terbuat dari makromolekul rantai panjang yang pada saat diaplikasikan pada tekstil berwarna. Penggunaan zat pengikat dalam pencapan pigmen adalah penting, karena zat pengikat ini akan dapat membentuk jaringan tiga dimensi sehingga zat warna dapat melekat pada serat (bahan). Zat pengikat dapat terbentuk sempurna dari beberapa macam resin sintetik yaitu resin termosetting dan termoplastik. Pada umumya zat pengikat tersebut adalah merupakan zat yang larut atau terdispersi dalam air atau dalam suatu pelarut, dan pada suhu tinggi akan berpolimerisasi.

Dalam penelitian ini digunakan zat pengikat jenis dispersi dengan ketahanan yang baik terhadap tegangan dalam mesin dan zat - zat kimia. Zat pengikat ini dipasarkan berupa cairan seperti susu, dimana zat pengikat jenis dispersi ini dibuat dengan suatu kopolimerisasi emulsi dari monomer - monomer olefin dalam medium cair. Gugus reaktif dalam kopolimer ini pada kondisi fiksasi tertentu akan menyebabkan ikatan silang dari molekul - molekul kopolimer, sehingga sifat tahan cuci yang baik dari pencapan pigmen ini disebabkan oleh ikatan silang tadi. Untuk mencapai kondisi fiksasi tersebut maka pencapan pigmen ini dilakukan pada suhu tinggi (curing), dan acramin SLN itu sendiri dapat bekerja dengan baik pada temperatur pemanasan diatas $100^{\circ} \mathrm{C}$.

Zat pengikat tersebut akan membentuk lapisan film yang tipis dan berikatan dengan seratnya, tetapi selain kemampuan untuk membentuk ikatan silang atau lapisan film maka zat pengikat tadi harus sanggup menutupi partikel - partikel zat warna pigmen, sehingga melindunginya terhadap pengaruh mekanis seperti gosokan, cucian, maupun terhadap zat kimia keadaan ini dapat terjadi dengan terbentuknya jaringan - 
jaringan yaitu adanya ikatan silang. Zat pengikat ini akan dapat membentuk jaringan tiga dimensi sehingga zat warna dapat melekat pada serat (bahan). Zat pengikat dapat terbentuk sempurna dari beberapa macam resin sintetik yaitu resin termosetting dan termoplastik. Dan pada umumya zat pengikat tersebut adalah merupakan zat yang larut atau terdispersi dalam air atu dalam suatu pelarut, dan pada suhu tinggi akan berpolimerisasi. Namun dengan demikian ikatan ikatan silang ini tidak boleh terjadi di bagian luar saja, melainkan waktu pembentukan lapisan film harus diberi kesempatan agar dapat terjadi ikatan silang di bagian dalam sehingga zat warna yang telah terikat dapat lebih terlindungi.

\subsection{Sistem Pengental}

Dalam pencapan dapat dipakai pasta cap dengan sistem pengental emulsi misalnya emulsi minyak dalam air ( o / $\mathrm{w}$ ) atau sistem emulsi air dalam minyak ( $\mathrm{w} / \mathrm{o}$ ) serta sistem larutan yaitu sistem yang bebas dari minyak.

Dalam kajian ini digunakan sistem larutan, sistem ini boleh dikatakan sebagai sistem baru, dimana pada pembentukan pasta pengentalnya hanya dipakai pengental dan air saja, tanpa pelarut pembantu. Sistem pelarut ini akan menggantung pada pengental yang dipergunakan, dan kekentalan pasta pada sistem larutan ini dapat diatur pada waktu proses pencapan. Selain itu sistem larutan ini mempunyai keuntungan - keuntungan dalam pemakaianya antara lain tidak memerlukan zat pengemulsi, sehingga masalah busa dapat dikurangi, tidak memerlukan katalis, kekentalan pasta akan terjadi dalam beberapa menit setelah pengental dicampur dengan air, tidak adanya ( dapat diperkecil ) bahaya ledakan karena dalam sistem ini bebas dari minyak, sistem ini mempunyai kestabilan kekentalan pasta dalam waktu relatif lama, pembuatan pastanya dapat dilakukan dengan mudah.
Namun demikian sistem larutan juga memiliki kekurangan - kekurangan, diantaranya adalah : sifat pegangan yang agak kaku setelah pasta dicapkan pada kain, kepekaannya terhadap elektrolit, dimana kekentalanya dapat menurun dengan adanya elektrolit.

Sedangkan sistem emulsi merupakan sistem pengental yang sudah umum dipakai dalam pencapan. Emulsi itu sendiri adalah suatu sistem heterogen, yang mengandung dua zat cair yang tidak saling bercampur. Dengan suatu teknik tertentu yaitu dengan menambahkan zat ketiga (zat pengemulsi), maka kedua zat cair tersebut dipaksa bercampur, yang satu terdispersi sempurna didalam cairan lainnya. Zat yang berada dalam bentuk terdispersi disebut fasa terdispersi (fasa dalam) sedang yang mengelilinginya disebut fasa terdispersi (fasa luar).

Dalam sistem emulsi ini sebagai pelarut pastanya adalah minyak tanah (kerosin) yang merupakan salah satu produk minyak bumi. Dahulu kerosin dibuat dari arang batu dengan cara penyulingan tetapi sekarang telah dapat dihasilkan dari minyak bumi, yang biasanya dibuat melalui sulingan langsung dan tidak dibuat dari hasil rengkahan. Sedangkan pemurniannya dilakukan dengan asam sulfat dan kemudian dinetralkan, adapun penghilangan warnanya dilakukan melalui proses absorbsi oleh puder penghilang warna.

\subsection{Zat Pelembut (Softener)}

Salah satu kekurangan yang terdapat pada pencapan zat warna pigmen diantaranya adalah nilai kekakuan kainnya khususnya dalam penggunaan pasta cap sistem larutan. Untuk mengatasi persoalan tersebut maka dapat dilakukan dengan menambahkan suatu zat pelunak (softener) ke dalam resep pasta capnya. Menurut golongannya maka zat pelunak dapat dibedakan menjadi 3 golongan yaitu :

- Golongan substansif.

- Fugitif.

- Golongan reaktif. 
Golongan substantif adalah pelunak kationik yang pada umumnya merupakan garam - garam amina atau garam amonium kwartenair. Sedangkan golongan fugitif yaitu yang hilang pada proses pencucian satu kali. Adapun golongan reaktif adalah yang mengadakan reaksi kimia dengan selulose, dan jenis ini tahan terhadap pengerjaan binatu (loundering) misalnya metilol stearamida dan etilen amine dari okta isosianat. Namun demikian saat sekarang ini sebagai zat pelunak juga dapat berfungsi sebagai zat penolaak air dalam jumlah kecil seperti: senyawa silikon dan derivat dari piridine yang berfunsi untuk memberi sifat lemas dan tahan noda.

\subsection{Proses Pencapan}

Proses printing (pencapan) adalah suatu proses untuk mewarnai bahan tekstil secara setempat dengan melekatkan zat warna pada kain secara tidak merata sesuai dengan motif yang diinginkan. Motif yang akan diperoleh pada kain cap nantinya harusnya dibuat dulu gambar pada kertas. Kemudian dari gambar ini masing - masing warna dalam komponen gambar yang akan dijadikan motif dipisahkan dalam kertas film. Dari kertas film inilah motif dipindahkan ke screen, dimana dalam screen ini bagian - bagian yang tidak ada gambarnya akan tertutup oleh zat peka cahaya sedangkan untuk bagian bagian yang merupakan gambar akan berlubang dan dapat meneruskan pasta cap ke bahan yang akan di cap.

Pada proses pencapan diperlukan pasta cap yang terdiri dari zat warna, pengental dan zat - zat pembantu yang tergantung pada jenis serat dan jenis zat warna yang digunakan. Sedangkan pembuatan pasta itu sendiri, pemilihan zat warna disesuaikan dengan bahan atau kain yang di cap, alat cap, sifat tahan luntur warna dan sifat - sifat lain yang diinginkan seperti kestabilan dalam pasta cap, kepekaan terhadap zat - zat kimia, ketahanan terhadap suhu tinggi dan sebagainya.
Adapun urutan pengerjaan proses pencapan yaitu meliputi tahapan sebagai berikut :
a. Pembuatan pasta cap.
b. Pencapan pada bahan.
c. Pengeringan pendahuluan.
d. Pemanas awetan.
e. Pencucian.

Pasta cap pada proses pencapan biasanya terdiri dari : Zat warna, pengental, zat - zat pembantu, Air. Dalam hal pembuatan cap ini, pemakaian zat warna, pasta pengental, zat - zat pembantu dan air pada umumnya diresepkan untuk pembuatan $1000 \mathrm{~g}$ pasta cap (Rasyid, 1976).

\subsubsection{Proses Pencapan Sistem Larutan}

Pada proses pencapan sistim larutan ini dapat dilakukan tahapan-tahapan pengerjaan seperti berikut :

a. Pembuatan pasta cap, yang meliputi pengerjaan : Pembuatan pasta pengental dengan pelarut air.

b. Zat warna, berikut zat-zat pembantu lain dicampurkan dalam pasta dan diaduk hingga homogen.

c. Pencapan pada bahan (kain).

d. Pengeringan pendahuluan.

e. Pemanas awetan.

f. Proses selanjutnya adalah pencucian.

Sebagaimana telah diuraikan terdahulu bahwa dalam sistem larutan ini sebagai pelarut pastanya hanya digunakan air saja, jadi bebas dari pelarut minyak dan zat pengemulsi, sehingga kemungkinan adanya efek sampingan seperti kerugian lingkungan karena pencemaran yang ditimbulkan oleh sisa - sisa (buangan) dari pasta cap yang mengandung minyak (emulsi) akan lebih kecil dibandingkan dengan sistem emulsi, begitu pula masalah busa dapat dikurangi.

\subsection{Pemanas Awetan}

Pada umumnya pemanas awetan ditentukan oleh penggunaan katalisnya. Untuk asam organik misalnya asam tartrat, perlu pengerjaan pada suhu $170{ }^{\circ} \mathrm{C}$ selama 2 
- 3 menit sedang untuk asam anorganik seperti: garam amonium perlu pengerjaan pada suhu 120-160 ${ }^{\circ} \mathrm{C}$ dengan waktu 2 - 3 menit. Pengerjaan dengan suhu dibawah 115 ${ }^{0} \mathrm{C}$ hanya akan melelehkan kondensat awalnya saja. Adapun pemanas awetan ini dimaksudkan untuk terjadinya ikatan silang dan polimerisasi dari zat pemikat pada temperatur dan waktu tertentu. Hal ini dapat dilakukan langsung setelah pengeringan pendahuluan atau dapat juga tanpa pengeringan pendahuluan, tetapi disimpan lebih dahulu selama satu malam.

\subsection{Mutu Pencapan}

Berbicara tentang mutu / kualitas pencapan ini maka tidak dapat terlepas dari beberapa faktor penentu mutu hasil pencapan diantaranya :

1. Design, yaitu mengenai ketajaman motif (dalam pengertian tidak ada efek gambar yang keluar dari motif).

2. Warna, dimana warna yang didapatkan mempunyai ketuaan tertentu tergantung dari besarnya zat warna yang terbawa dan terikat oleh serat begitu pula mengenai kecerahan warnanya.

3. Ketahanan luntur warna, hasil pencapan akan diperhatikan tentang ketahanan lunturnya seperti: ketahanan luntur warna terhadap gosokan, terhadap pencucian , terhadap cahaya dan sebagainya.

4. Faktor - faktor penentu lainnya yang berpengaruh terhadap mutu hasil pencapan seperti: penilaian kekakuan kain karena adanya zat pengikat, dan lainnya.

\section{METODE PENELITIAN}

\subsection{Metode}

Penelitian dilakukan menggunakan metode eksperimental laboratorik, yaitu melakukan percobaan - percobaan dan pengujian terhadap hasil percobaan yang telah dilakukan.

\subsection{Percobaan}

Pada tahap ini dilakukan proses pencapan kain kapas (100\%) dengan zat warna pigmen Acramin dengan pengental sintetik Alcoprint menggunakan pasta cap bebas dari pelarut minyak (disebut sistem larutan) dan pasta cap sistem emulsi yang umum dipakai (sebagai pembanding).

\subsection{Alat - alat dan Bahan yang Di gunakan \\ Alat - alat yang digunakan dalam} percobaan yaitu : meja pencapan, screen dan rakel, gelas piala, gelas ukur, pengaduk kaca, timbangan (neraca), pengaduk (mixer), mesin pemanas awetan (oven), pipet.

Sedangkan bahan - bahan yang digunakan yaitu :

a. Kain Kapas.

b. Pengental Alcoprint PTF (sintetik).

c. Zat warna pigmen Acramin Blue P 2G.

d. Zat-zat pembantu yang terdiri dari :

Minyak tanah, air, Amonia $27 \%$, Avivan SLN / Softener.

e. Diamonium phospat, Emulgator W, Acrafix M, Acramin Binder SLN.

\subsection{Prosedur Pencapan}

a. Resep pencapan menggunakan pengental Alcoprint PTF pada pasta cap sistem larutan :

Zat warna pigmen $\quad: 20 \mathrm{~g}$

Alcoprint PTF (divariasi) : 5;10;15;20;25 g

Acramin Binder $\quad: 150 \mathrm{~g}$

Amonnia 27\% $: 5 \mathrm{~g}$

Air

$: \mathrm{xg}$

$$
1.000 \mathrm{~g}
$$

Dengan suhu pemanas awetan : 130, 140 dan $150^{\circ} \mathrm{C}$.

b. Resep pencapan menggunakan pasta cap sistem emulsi yang biasa dipakai : 
Tabel 2. Rata - Rata Nilai Ketuaan Warna

\begin{tabular}{ccccccc}
\hline $\begin{array}{c}\text { SUHU } \\
\left({ }^{\mathbf{O}} \mathbf{C}\right)\end{array}$ & FILTER & \multicolumn{5}{c}{$\begin{array}{c}\text { NILAI KETUAAN WARNA } \\
\text { KOLAI REFLEKTANSI WARNA) }\end{array}$} \\
& & $\mathbf{5}$ & $\mathbf{1 0}$ & $\mathbf{1 5}$ & $\mathbf{2 0}$ & $\mathbf{2 5}$ \\
\hline \multirow{3}{*}{130} & MERAH & 9,56 & 10,00 & 10,35 & 10,53 & 11,00 \\
& BIRU & 47,79 & 49,07 & 48,95 & 50,25 & 53,34 \\
& HIJAU & 13,12 & 13,28 & 13,60 & 14,80 & 14,94 \\
& & & & & & \\
140 & MERAH & 9,80 & 10,20 & 11,00 & 11,30 & 11,20 \\
& BIRU & 48,90 & 51,20 & 53,00 & 53,20 & 54,20 \\
& HIJAU & 13,60 & 14,00 & 14,60 & 15,20 & 15,13 \\
& & & & & & 11,20 \\
150 & MERAH & 10,50 & 10,40 & 11,20 & 11,50 & 11,80 \\
& BIRU & 49,00 & 51,60 & 53,20 & 53,40 & 53,10 \\
& HIJAU & 13,90 & 14,20 & 15,40 & 15,60 & 14,70 \\
\hline
\end{tabular}

Tabel 3. Rata - Rata Nilai Ketuaan Warna dengan Pasta Cap Sistem Emulsi (dengan pelatut minyak)

\begin{tabular}{cc} 
FILTER & NILAI KETUAAN WARNA \\
& \\
\hline MERAH & 13,00 \\
BIRU & 50,80 \\
HIJAU & 14,80 \\
\hline
\end{tabular}

Tabel 4. Nilai Kerataan Warna (Beda Warna) Kain Hasil Pencapan dengan Pasta Cap Bebas Pelatut Minyak dan Pasta Cap Sistem Emulsi

\begin{tabular}{|c|c|c|c|c|c|c|}
\hline \multirow[t]{2}{*}{ PASTA CAP } & \multirow[t]{2}{*}{$\begin{array}{c}\text { SUHU } \\
\left({ }^{0} \mathrm{C}\right)\end{array}$} & \multicolumn{5}{|c|}{$\begin{array}{l}\text { NILAI KETUAAN WARNA (BEDA WARNA } \triangle E \text { ) } \\
\text { KONSENTRASI PENGENTAL ( gram ) }\end{array}$} \\
\hline & & 5 & 10 & 15 & 20 & 25 \\
\hline \multirow{3}{*}{$\begin{array}{l}\text { SISTEM } \\
\text { LARUTAN }\end{array}$} & 130 & 2,86 & 2,98 & 3,35 & 3,23 & 3,20 \\
\hline & 140 & 2,79 & 3,07 & 3,05 & 3,25 & 3,24 \\
\hline & 150 & 3,12 & 3,18 & 3,27 & 3,30 & 3,24 \\
\hline $\begin{array}{l}\text { SISTEM } \\
\text { EMULSI }\end{array}$ & \multicolumn{6}{|c|}{3,46} \\
\hline
\end{tabular}

Zat warna pigmen

$: 20 \mathrm{~g}$

Pengental emulsi $\quad: \mathrm{x} \mathrm{g}$

Acrafix M : $20 \mathrm{~g}$

Acramin Binder $\quad: 150 \mathrm{~g}$

Diamonium phospat (DAP) : $25 \mathrm{~g}$

$$
1.000 \mathrm{~g}
$$

Pengental emulsinya terdiri dari :

Manuteks RS 5\%

$: 100 \mathrm{~g}$

Minyak tanah

: $700 \mathrm{~g}$

Emulgator

: $50 \mathrm{~g}$
Air

$: 150 \mathrm{~g}$

$1.000 \mathrm{~g}$

Dengan suhu pemanas awetan sebesar $150^{\circ}$ C.

\subsection{Pengujian}

Pengujian ini dilakukan dengan baik terhadap hasil pencapan dengan pasta cap sistem larutan maupun terhadap hasil 
pencapan dengan pasta cap sistem emulsi, yaitu uji ketuaan warna (beda warna).

Pengujian dilakukan mengunakan Colorimeter dari Photovolt Corporation, Model 610 dengan tristimulus filter (merah, biru, hijau) buatan USA. Pada pengujian ini akan diperoleh harga - harga R, G, dan B.

$\mathrm{R}$ : Reflektansi dari contoh uji dengan penyinaran filter merah.

$\mathrm{G}$ : Reflektansi dari contoh uji dengan penyinaran filter hijau.

B : Reflektansi dari contah uji dengan penyinaran filter biru.

Dari harga - harga R, G, B tersebut maka beda warna $(\Delta \mathrm{E})$ hasil pencapan dapat dihitung dengan menggunakan rumus Adam Nicherson sebagai berikut :

$\Delta E=40 \sqrt{\left(0,23 \Delta_{y}\right]^{2}+\left[\Delta\left(V_{y}-V_{y}\right)\right]^{2}+\left[0,4, \Delta\left(V_{2}-V_{y}\right)\right]^{2}}$

Dimana :

$\Delta \mathrm{E}=$ Beda Warna Dalam Satuan Adam Nicherson (AN).

$\mathrm{V}_{\mathrm{x}} ; \mathrm{V}_{\mathrm{y}} ;$ dan $\mathrm{V}_{\mathrm{z}}$ dapat dicari pada tabel

Evaluasi, beda warna yang diperkenankan dalam perdagangan ditentukan toleransinya yaitu antara $3-6$ AN tergantung pada macam warnanya. Hasil pengujian, hasil pengujian ketuaan warna yang dinyatakan sebagai nilai beda

\subsection{Hasil Pengujian}

Hasil pengujian kualitas (ketuaan warna dan kerataan warna) dapat terlihat pada tabel 1 , tabel 2 dan tabel 3 diatas.

\section{PEMBAHASAN}

\subsection{Ketuaan Warna}

Berdasarkan hasil pengujian serta analisa data hasil pengujian ketuaan warna, dapat dijelaskan bahwa pemakaian jumlah pengental yang makin tinggi, relatif akan berpengaruh pada warna yang terjadi, kemungkinan karena fungsi pengental sebagai zat pembantu pada proses terjadinya ikatan silang sehingga zat warna melekat pada bahan. Ikatan silang yang terjadi pada suhu $130^{\circ} \mathrm{C}$ telah terbentuk dengan sempurna, hal ini dapat terlihat pada tabel bahwa pada suhu tersebut ternyata mempunyai nilai reflektansi yang baik (kecil). Pengamatan lebih lanjut memberikan petunjuk bahwa pada suhu yang sama, dengan penambahan jumlah pengental memberikan nilai / angka reflektansi berbeda.

Dicapainya nilai warna yang cukup baik ini mungkin karena pada pasta capnya tidak ada zat-zat yang mengadakan reaksi dengan zat warna sehingga tidak merubah struktur dari zat warnanya. Sebagaimana diketahui bahwa zat warna pigmen mempunyai sifat yang baik terhadap suhu yang tinggi sehingga pada pemanas awetan tidak mengalami perubahan warna yang signifikan, maka perubahan suhu dalam proses pemanas awetan pada pencapan pigmen dengan pasta cap sistem larutan ini relatif tidak berpengaruh pada ketuaan warna yang terjadi. Pengamatan secara visual, untuk warna cerah maka ketuaan warna dengan jumlah pengental yang berbeda akan memberikan hasil warna yang hampir sama, karena pada warna cerah ini perbedaannya kecil sehingga kurang tampak pada warna. Tetapi untuk warna tua / gelap ketuaan warnanya dapat terlihat perbedaanya. Oleh karenanya untuk ketelitian nilai reflektansi warnanya digunakan alat yang bekerja secara elektris yaitu Colorimeter Photovolt. 


\subsection{Kerataan Warna $(\Delta E)$}

Penentuan toleransi perbedaan warna yang diperkenankan di dalam perdagangan adalah berkisar antara $3-6$, tergantung pada macam warnanya. Dalam penelitian ini beda warna yang didapat akibat perbedaan suhu perbedaan suhu pemanas awetan dan jumlah pengentalnya sebagaimana terlihat pada tabel hasil pengujian yang menunjukkan bahwa nilai beda warna untuk semua kondisi pengerjaan masih termasuk dalam batas toleransi yang diijinkan (kecuali pada variasi suhu $130^{\circ} \mathrm{C}$, konsentrasi pengental 5 dan 10 gram, serta pada suhu $140^{\circ} \mathrm{C}$ konsentrasi pengental 5 gram). Dari tabel tersebut menunjukkan juga bahwa hasil pencapan mempunyai nilai kerataan warna yang baik.

Nilai reflektansi hasil warna pencapan dengan pasta cap sistem larutan dapat dikatakan sama dengan penggunaan pasta cap sistim emulsi, bahkan beberapa harga dapat lebih baik dari sistem emulsi.

\section{KESIMPULAN}

1. Kain dari serat kapas dapat diproses pencapan dengan zat warna pigmen menggunakan pasta cap sistem larutan dan memberikan hasil pencapan yang baik.

2. Jumlah pemakaian pengental berpengaruh terhadap ketuaan dan kerataan warna hasil pencapan yang cukup signifikan (makin tinggi jumlah pengental yang dipakai ketuaan dan kerataan warna yang terjadi makin baik), sedangkan semakin tinggi suhu memanas awetan relatif tidak berpengaruh terhadap ketuaan dan kerataan warna hasil pencapan.

3. Warna yang dihasilkan dari pencapan menggunakan pasta cap sistem larutan dengan pengental Alcoprint PTF dan zat warna pigmen mempunyai nilai yang sama (baik) apabila dibandingkan dengan menggunakan pasta cap sistem emulsi.
4. Kondisi optimum yang didapatkan pada pencapan kain kapas dengan pasta cap sistem larutan dari zat warna pigmen diperoleh penggunaan pengental sebanyak 20 gram dan suhu pemanas awetan $150^{\circ} \mathrm{C}$.

\section{DAFTAR PUSTAKA}

Adamson, 2000, Physical Chemistry of Surface, New York : John Willey Interscience Publishing Corporation.

Anonim, 1975, Standar Industri Indonesia ( SII ) tentang Cara Uji Tekstil, Departemen Perindustrian RI.

Anonim, 1993, Alginates, Alginate Industries Limited, London.

Dautyagi S., 2013, Fundamentals of textiles and their care, $1^{\text {st }}$ edition, Chapman and Hall Ltd, London.

Isminingsih Gitopadmoyo, 1978, Pengantar Kimia Zat Warna, cetakan pertama, ITT, Bandung.

Jones F George, 1996, Pigment for Textile, American Dyestuff Reporter, Volume 35.

Mathews, 1993, Textile Fibre, New York : John Willey \& Sons Inc.

Maurersberger.HR., 1995, Pigment Printing Aplication To Textile, American Dyestuff Reporter, Volume 31.

Oriyati S. et al., 1982, Teori Penyempurnaan Tekstil III, Edisi pertama, Jakarta: Departemen P \& K 1982.

Paul Becher. 1987, Emulsion Theory and Practice. $3^{\text {rd }}$ edition New York: Reinhold Publishing Corporation.

Perikh DV, 2005, Pigment Printing To Textile, American Dyestuff Reporter, Volume 59.

Rasyid Djufri et.al, 1976, Teknologi Pengglantangan Pencelupan dan Pencapan, Cetakan ke 2, ITT, Bandung.

Soeparman,et.al, 1977, Teknologi Penyempurnaan Tekstil, Cetakan ke 2, ITT, Bandung.

Supriyono, 1974, Serat - Serat Tekstil, Cetakan ke 2, ITT, Bandung. 